\title{
TEACHING LISTENING USING TOEIC APPLICATION
}

\author{
Tuti Karmiati $^{1}$, Yulyayu Kurniawati ${ }^{2}$ \\ ${ }^{1}$ IKIP Siliwangi \\ ${ }^{2}$ IKIP Siliwangi \\ ${ }^{1}$ karmiati_tuti@yahoo.com, ${ }^{2}$ yulyayukurniawati@yahoo.com
}

\begin{abstract}
In a modern era many students like to learn english easily, many students learn english with listening something, like listening music in their mobile phone or in the radio, in this era we can find the western song in many place, like in the mall, radio, and so on. So we can hear the western song and learn listening english easily. Teaching listening is teaching students to learn to listen to languages and conversations using the ear. The reason for students being able to listen to spoken English is by letting them listen to variations and accents rather than just the teachers voice with its own idiosyncrasies. Listening is a very important skill in language learning and can't be underestimated especially in an academic context and is separated in language so that listening has an important role in teaching the language including teaching English. The purpose of this study is to find out how English teacher use TOEIC applications in listening to students and how students respond to the use of TOEIC applications in student listening. Most students argue that the hardest is listening, and some of them even have difficulties in understanding the teachers who are teaching English. It states that students still have difficulty in listening and become one of the obstacles in learning English. The used of media as a tool or means in teaching and learning English that is very useful for students and teachers. This research is to know how big influence of TOEIC application media in learning to listen English. The design taken in this study is pre-experimental design and the author also uses quantitative research methods in conducting research. Subjects in this study were students of class XI AKP1 in SMKN 2 Karawang which amounted to 32 students as a sample. The author used a listening test to collect data. The procedure used in this research is pretest, treatment and posttest. Pretest was given to students to measure their knowledge before treatment, treatment is the researcher teach about TOEIC application, and posttest is a final result from the treatment.
\end{abstract}

Keyword: Teaching Listening, Listening, TOEIC Application

\section{INTRODUCTION}

Listening is an important skill in language learning and it can't be underestimated especially in academic context and is separated in language therefore listening has an essential role in teaching the language including English language teaching. According to (Nation \& Newton, 2009) Listening is a natural predecessor to speak at an early stage language development in a person's first language learning (naturalistic the acquisition of other languages) depends on hearing

Whenever and wherever sometimes we are hear something that we get from various sources, there is the model of listening that was explained by (Nation \& Newton, 2009) Listening was traditionally seen as a passive process by which the listener receives information sent by a speaker. More recent models view listening as a much more active and interpretive process in which the message is not fixed but is created in the interactional space between participants. 
So, the media that choosed and used for this research is TOEIC, because TOEIC expected to be able to support and improve listening skill for the students. According to (Lougheed, 2007) The Test of English for International Communication (TOEIC) is a multiple choice test of English for adult, nonnative speakers of the language. TOEIC Application is able to help improve student learning innovation by way of more interesting teaching by learning listening using the media images that make students not bored in the class. Of course this test have a limitation of time, the new actual time for the TOEIC test is approximately two hours. Additional time is required to answer questions about yourself on the Answer Sheet. You should allow up to three hours to take the test. We choosed this technique because TOEIC test is designed to test your proficiency in English.

\section{METHOD}

Research methodology is to collect research data, the writers using quantitative research. For it calculation used numerical data statistics used SPSS. According to (Arikunto, 2013) the method of research was the way used by researchers in collecting research data. This research was a quantitative approach, because to collection the data using numerical data statistic. According to (Creswell, 2008) Quantitative research is a means for testing objective theories by examining the relationship among variables. These variables. in turn, can be measured. typically on instruments, so that numbered data can be analyzed using statistical procedures. The final written report has a set structure consisting of introduction. literature and theory, methods. results, and discussion.

The purpose of the writer conducted pre-experimental design with one group pre-test and posttest. According to (Hussein, 2012) Pre-experimental designs are not really considered model experiments because they do not account for extraneous variable which may have influenced the results. Thus, the internal validity of such a design is also questionable. However, they are easy, useful ways of getting introductory information on research questions. This writer give pretest, treatment and post-test by giving listening test using TOEIC application. Pretest before treatment, after pretest students are given treatment, and after treatment students are given posttest.

This research is to find out whether TOEIC is effective or not in improving student's listening skill, and this research taken data through pre-test, treatment and post-test. Pre-test was given to students to find out their knowledge before giving treatment, treatment is the writers taught the students about listening using TOEIC application, and post-test was given to students to find out the final result of the treatment.

\section{RESULT AND DISCUSSION}

\section{Results}

Data analysis was done to know the different score pretest and posttest of the students' in teaching listening using TOEIC application. The next step was analyzing those data using paired sample t-test by using SPSS 21. Before the t-test, the researcher must determine whether the pretest and posttest scores are normally distribution or not, if the pretest and posttest scores are normally distribution then the homogeneity test is performed and if both data are normal distributed and have the same variance then paired sample t- test (t-test).

Table 4.2 The Student's Scores 


\begin{tabular}{|l|l|l|}
\hline NO STUDENT & $\begin{array}{l}\text { PRETEST } \\
(\text { X1 })\end{array}$ & $\begin{array}{l}\text { POSTTEST } \\
(\text { X2 })\end{array}$ \\
\hline STUDENT 1 & 70 & 90 \\
\hline STUDENT 2 & 55 & 80 \\
\hline STUDENT 3 & 65 & 85 \\
\hline STUDENT 4 & 75 & 90 \\
\hline STUDENT 5 & 65 & 85 \\
\hline STUDENT 6 & 70 & 90 \\
\hline STUDENT 7 & 65 & 80 \\
\hline STUDENT 8 & 60 & 95 \\
\hline STUDENT 9 & 65 & 85 \\
\hline STUDENT 10 & 70 & 80 \\
\hline STUDENT 11 & 75 & 90 \\
\hline STUDENT 12 & 60 & 75 \\
\hline STUDENT 13 & 60 & 85 \\
\hline STUDENT 14 & 85 & 100 \\
\hline STUDENT 15 & 60 & 75 \\
\hline STUDENT 16 & 75 & 90 \\
\hline STUDENT 17 & 60 & 85 \\
\hline STUDENT 18 & 65 & 80 \\
\hline STUDENT 19 & 70 & 80 \\
\hline STUDENT 20 & 75 & 95 \\
\hline STUDENT 21 & 70 & 90 \\
\hline STUDENT 22 & 80 & 95 \\
\hline STUDENT 23 & 70 & 85 \\
\hline STUDENT 24 & 75 & 90 \\
\hline STUDENT 25 & 70 & 85 \\
\hline STUDENT 26 & 70 & 85 \\
\hline STUDENT 27 & 65 & 90 \\
\hline STUDENT 28 & 75 & 95 \\
\hline STUDENT 29 & 65 & 80 \\
\hline STUDENT 30 & 50 & 70 \\
\hline STUDENT 31 & 60 & 80 \\
\hline STUDENT 32 & 65 & 85 \\
\hline SUM & 2160 & 2745 \\
\hline MEAN & 67.5 & 85.83 \\
\hline & & \\
\hline & 75 & 95 \\
\hline
\end{tabular}

Based on the table above, the result of pretest showed that the highest is 85 and the lowest score is 50. For the posttest showed that the highest score is 100 and the lowest is 70 . While the total Sum $(\Sigma)$ for pretest is 2160 and for posttest score 2745 and the mean value of pretest score is analysis data.

After the knowing the result of the data pretest and posttest, the writers look for result from test of normality. The normality test was to determine the data and to calculate how likely the variables underlying the data set to be distributed normally. According to (Suprijadi \& Kaswan, 
2016) normality or bell shaped curve is a theoretical distribution which shows the frequency or probably of all the possible values that a continuous variable can takes.

Table 4.2

Test of Normality

Tests of Normality
\begin{tabular}{|l|l|l|l|l|l|l|}
\hline & \multicolumn{3}{l}{ Kolmogorov-Smirnov ${ }^{\mathrm{a}}$} & \multicolumn{3}{|l|}{ Shapiro-Wilk } \\
\cline { 2 - 7 } & Statistic & df & Sig. & Statistic & df & Sig. \\
\hline PRETEST & .132 & 32 & .167 & .961 & 32 & .294 \\
POSTTES & .141 & 32 & .104 & .956 & 32 & .207 \\
T & & & & & & \\
\hline
\end{tabular}

a. Lilliefors Significance Correction

Based on the table above is known that the significance value from pre-test is 0.294 and from the post test is 0.207 . Both value from pre-test and post-test are higher than 0.05 . The sig/p value on pre-test is 0.294 and it is higher than $0.05(0.294>0.05)$ means that the data is in normally distribution. Then, for post-test score the value of sig/p is 0.207 and that is higher than $0.05(0.207>0.05)$ means that the data is in normal distribution. It also means that $\mathrm{HO}$ is accepted and Ha is rejected. So, it can be interpreted that both of data (pretest and posttest score) are in normally distribution.

After the knowing the result of normality, the writers look for result from test of homogeneity. Homogeneity is the test of the equality of two or more distribution variances. According to (Suprijadi \& Kaswan, 2016) homogeneity is the degree to which the variances of two or more samples are similar or homogeneous.

Table 4.3

Test of Homogeneity of Variances

Test of Homogeneity of Variances
PRETEST DAN POSTTEST
\begin{tabular}{|l|l|l|l|}
\hline $\begin{array}{l}\text { Levene } \\
\text { Statistic }\end{array}$ & df1 & df2 & Sig. \\
\hline .371 & 1 & 62 & .545 \\
\hline
\end{tabular}

Based on the table above is known that the sig or p-value is 0.545 higher than 0.05 means $\mathrm{H} 0$ is accepted and $\mathrm{Ha}$ is rejected. So, it can be interpreted that the data is homogeneity.

After the knowing the result of homogeneity, the writers look for result from test of paired sample test. Both data pretest and posttest score are normally distribution and have homogeneous variance, then do different test of two paired samples through SPSS 21.0 program 
using Paired Sample T-Test with significance level 0,05. According to (Suprijadi \& Kaswan, 2016) t-test is a parametric test which is used to discover whether there are statistically significant differences between the mean of one group pretest and posttest. To know the paired samples correlations between the students' score of pretest and posttest is described in the following table

Table 4.4

Paired Sample Test

Paired Samples Test

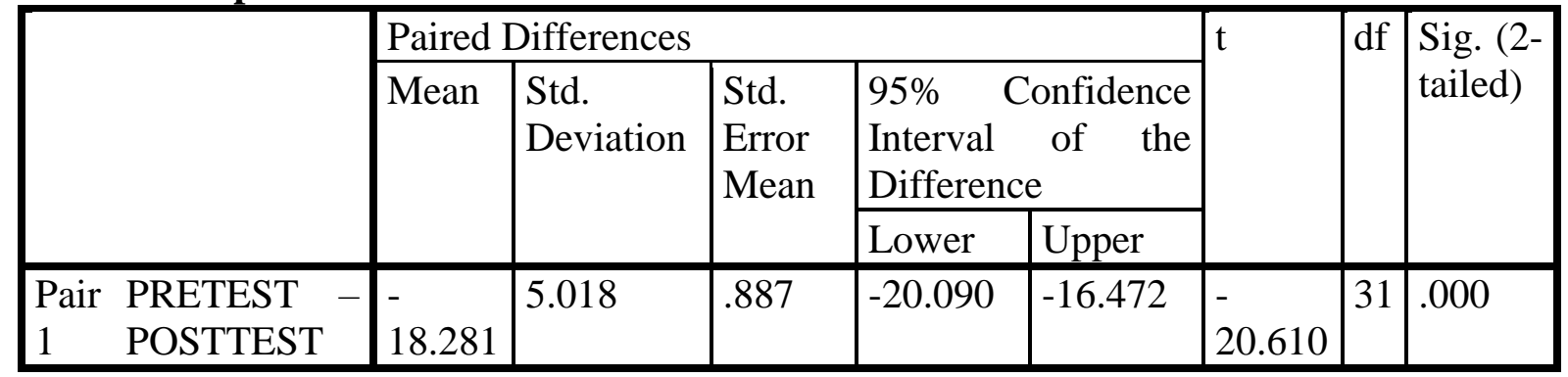

Based on the table 4.5, output paired samples test shows the result of compare analysis with using T test. Output shows mean pre-test and post-test is -18.281 , standard deviation is 5.018, mean standard error is 0.887 . The lower different is -20.090 and upper different is -16.472 . The result test $\mathrm{t}=-20.610$ with $\mathrm{df}=31$ and significance is 0.000 .

Because significance 0.000 lower than $0.05(0.000<0.05)$ means that $\mathrm{Ho}$ is rejected and $\mathrm{Ha}$ is accepted. Therefore, it concluded that there is the significant differences between pretest and posttest score where mean of posttest is 86.71 higher than mean of pretest is 68.28 means that there is effect of TOEIC application of the eleventh grade at SMKN 2 Karawang.

\section{DISCUSSION}

The data described in the research results are authenticated by doing face-to-face meetings with students for 7 meetings including pretest and posttest. For the learning activities conducted as many 5 meetings. Normality test results used SPSS 21 against pretest and posttest show that the data is normally distributed, therefore the testers then use the homogeneity test to ensure normal distributed data, after testing using the normal result homogeneity then followed by $\mathrm{T}$ test to ensure that significant $0.000<0.005$.

Based on the descriptive statistics above, the average posttest (86.71) is greater than pretest (68.28). This means that there is an increase in student test results, on average, between before and after treatment. In addition, the result of significance the average difference of Sig (2-tailed) is 0.000 . This means that $\mathrm{Sig}$ (2-tailed) results obtained $0,000<0.005$. It can be concluded that using of TOEIC application can improve students listening skills.

Therefore the research listening using TOEIC application succeeded. TOEIC is media students enjoy listening in learning and resulting in improved student learning. According to (Lougheed, 
2007) the test of English for International Communication (TOEIC) is a multiple choice test of English for adult, nonnative speakers of the language. TOEIC test is one of the most common internationally recognized English proficiency exams in the world.

\section{CONCLUSION}

The writer concludes that teaching listening comprehension by using TOEIC applications was effective in improving students' listening skills. This was supported by data analysis results, where the average posttest (85.78) was greater than pretest (67.5). Data show that there was increase in writing learning as a result of posttest improvements over pretest results. In addition, the average difference value of significance of Sig $(2$-tailed $)=0.000<0.05$.

\section{ACKNOWLEDGEMENT}

Alhamdulillahirobbil'alamin, praise to Allah SWT who has enable the writers to finish this researcher paper. Peace and solutions are always for Rosulullah SAW. During the paper the writer obtained a lot of help. Suggestions and motivations from many people. For that reason, the writer would like to express his gratitude to:

1. Dr.H. Heris Hendriana, M.Pd, as the Head of IKIP Siliwangi,

2. Dr. Irma Savitri Sadikin, M.P, as the Head of English Education Study Program,

3. Dr. Irma Savitri Sadikin, M.Pd, as the first supervisor,

4. Trisnendr Syahrizal, S.Pd, M.Hum as the second supervisor,

5. All lecturer and staff of English Education Study Program of IKIP Siliwangi Bandung,

6. Our beloved parents who had given prayer, help, and support,

7. Our beloved friends besties,

8. Students of KR 2014 class of English Education Study Program who had given spirit and cooperation,

Finally, thanks are due to all people who had prayed and supported the writing who can not be mentioned one by one. May Allah bless them all.

\section{REFERENCES}

Arikunto, S. (2013). Praktik, Prosedur Penelitian. Suatu Pendekatan. jakarta: rineka cipta.

Creswell, J. W. (2008). Research Design. Qualitative, Quantitative, and Mixed Methods Approaches. (SAGE, Ed.). los angeles.

Hussein, T. (2012). Linguistics., A Dictionary of Research Methodology and Statistics in Applied. iran: rahnama press.

Lougheed, L. (2007). Preparation Series for The New TOEIC Test, 4th. new york: pearson education.

Nation, \& Newton. (2009). Teaching ESL/EFL Listening and Speaking. new york: routledge.

Suprijadi, D., \& Kaswan. (2016). Education, Research In English Language. BANDUNG: putra praktisi. 